concentration. When it is remembered that the Dead Sea sinks to depths of 400 metres we may realize that very great deposits must be supposed existing immediately around and beneath its waters if Mr. Ackroyd's views are to be entertained. The fact quoted by Mr. Ackroyd that "common salt in the southern parts of the lake forms quite a paste" will evidently not suffice.

It is needless to quote here the views of geologists on this question. The observations of Lartet (Bull. S.G.F., [2] xxiii, p. 719) quoted by De Lapparent show that “ tous les sels contenus dans l'eau de la mer Morte et celle du Jourdain sont également (à l'exception peut-être du brome) renfermés dans les eaux des sources chaudes du même bassin, notamment celles de Zara, de Callirhö̈, et d'Emmaüs" (vol. i, p. 488). The absence of iodine, so characteristic of seawater, the presence of bituminous and sulphurous odours, the very local variations in composition, further lead $M$. de Lapparent to the view that the intervention of sea-water cannot be looked for in accounting for its composition; but that it represents a fresh-water lake modified by volcanic agencies of comparatively recent date.

Having no leisure to discuss the matter further, I would close my remarks by stating once more that the carriage of sea-salts into many inland lakes is very certainly a fact. The difference between Mr. Ackroyd's and my own views on the matter is one of degree only. If my own original estimate, that 10 per cent. of river chlorine is from the ocean, were correct, this would involve considerable importations of sea-salts in process of time into inland waters.

\title{
V.-The Sequence of the Tertiary Igneous Rocks of Skye.
}

By Alfred Harker, M.A., F.G.S.

(Published by permissiou of the Director of the Geological Survey.)

THIS communication is the outcome of work carried out during the years 1895-1901 in the service of the Geological Survey of Scotland. Although this systematic work has been confined to the Isle of Skye, information incidentally acquired, and the published literature of the British Tertiary rocks, indicate for the conclusions arrived at a much wider application. In this place the results must be set down without the detailed observations upon which they are based.

Here, as in numerous other areas and at various geological periods, igneous activity has manifested itself successively under three different phases, the Volcanic, the Plutonic, and the Phase of Minor Intrusions (often called the Dyke Phase). There is further an important distinction to be observed, neglecting which the whole sequence is thrown into confusion. The various events recorded in the succession fall into two distinct categories of very different orders, which may be termed the Regional Series and the Local Series. Those of the former class affected a very wide area-perhaps in some cases the whole Brito-Icelandic Province, extending from the 
British Isles to beyond the Arctic Circle. The episodes of the Local Series, on the other hand, were closely related to certain special foci of activity, declared at a very early epoch, one of which was situated beneath what is now the mountain district of Central Skye. While events of the two classes often alternated in our area, and are integral parts of one complete record, they may be regarded as in some degree independent and as bound up with two distinct orders of crust-movements, viz. the continent-building and the mountain-building respectively. Of the two parallel series of eruptions, the Regional retained throughout a basic character, while the Local developed wide petrographical differences among the several groups. It follows that the successive episodes of the Regional Series are much more difficult to separate and arrange in order than those of the Local Series, and the following condensed scheme is confessedly imperfect, especially as regards the basic lavas and the basic dykes.

(0) Pre-Volcanic Phase : Local Series.-Here may be noticed certain plutonic intrusions nowhere exposed at the surface and known only from fragments in the volcanic agglomerates. They are confined to the central mountain district, and include, in order, (a) gabbro and (b) granite.

(1) Volonnic Phase.-Regional activity almost continuous; local chiefly confined to two well-marked episodes.

Regional Series.-Fissure-eruptions of basic (with some sub-basic) lavas throughout the region. Besides the prevalent olivine-basalts, there $\operatorname{are} \operatorname{som} \theta$ hypersthene-basalts, augite-andesites, etc., but no ordered sequence has been made out.

Local Series. - Central, not fissure-eruptions.

(a) Paroxysmal outbursts at certain centres, marked by great accumulations of volcanic agglomerate; the large vents confined to the mountain district. The chief masses of agglomerate underlie all the lavas, and thus represent the earliest overt manifestation of igneous activity.

(b) Eruptions, only in part paroxysmal, of intermediate and acid rocks in one limited area on the northern border of the Cuillins. Generalized sequence : (i) trachytes, (ii) rhyolitic tuffs and breccias, (iii) rhyolites. This group is intercalated as a local episode in the midst of the basic lavas.

(2) Putonic Prasse.-Regional activity in abeyance; local at maximum of intensity and at the same time narrowly localized.

Local Series. - Plutonic intrusions in the forms of complex laccolitic masses and bosses. Three groups, in order of increasing acidity, with little or no intervals.

(a) Peridotites of the south-west Cuillins; viz., olivine-anorthite rocks, picrites, and typical peridotites, including dunite.

(b) Gabbros of the Cuillins, etc.

(c) Granites and granophyres (plutonic) of the Red Hills.

(2 to 3) Transitional Phase, Local Series only.-The phase of Minor Intrusions shows, as compared with the Plutonic, a reversal of order among the groups of local intrusions. There seems to have 
been a certain critical epoch, at which in some places basic and acid rocks were intruded almost simultaneously, the basic, howerer, being slightly the earlier. Remarkable reactions resulted between the two rocks so intimately associated. Here belong :-

Composite sills and dykes, composed of basic and acid rocks, usually with triple symmetry; occurring along a belt outside the border of the Red Hills.

(3) Prase of Minor Intrusions in the form of sills, sheets, and dykes. Resumption of regional activity in a new form (intrusive instead of extrusive); local activity at certain epochs. Waning intensity indicated during this phase by generally diminishing volume of intrusions, both individually and as groups, and, at least in the Local Series, by intervals of quiescence.

Regional Series.-Rocks still exclusively basic and (exceptionally) sub-basic, so that no law of chemical variation in time can be laid down.

(a) Great group of basic sills. These are by far the most important intrusive rocks in the whole suite, making up more than half of the total thickness of the basaltic group over most of the area, besides appearing in considerable force in the underlying Jurassic. Their intrusion constituted the first episode of the Phase of Minor Intrusions. They are here included in the Regional Series as having clearly no relation to the special focus of Central Skye. They are most developed in the north and west of the island, and die out towards the mountains.

(b) Basic dykes, mostly with directions near N.W.-S.E., intruded in vast numbers throughout the region at various epochs, the division into successive groups being possible only in a very partial degree. These basic dykes are to be regarded as self-constituted intrusions; others of earlier dates being merely the feeders of lava-flows and sills.

Local Series.-Three chief groups, having restricted areas of distribution, each standing in relation with the corresponding plutonic centre. Order of increasing basicity.

(a) Minor acid intrusions (dykes, irregular sills, etc.). Area of distribution a roughly elliptic tract, centring in the granite of the Red Hills but extending beyond, with long axis in the general direction of the dykes (N.N.W.-S.S.E.).

(b) Minor basic intrusions. Area of distribution nearly coincident with the gabbro of the Cuillins. The most remarkable set of intrusions takes the form of numerous parallel sheets inclined inwards, towards the centre of the area. In addition there is a radiate set of dykes, partly feeders of the sheets, partly older; also, much less perfectly developed, a tangential set of dykes.

(c) Minor ultrabasic intrusions, in the form of a radiate set of dykes; distributed with reference to the Cuillins, or rather to the south-western half of the Cuillin area, where the plutonic peridotites occur.

Subsidiary Groups.-There remain certain groups of dykes, of small importance as regards number and magnitude, concerning which more data are needed. They belong in all cases to very late episodes, but their precise places in the sequence have not been satisfactorily fixed. 
(a) Trachyte and trachy-andesite dykes. Most of these, occurring about Broadford and in the Sleat district, seem to belong to a group which has its chief area of distribution farther south-east, on the Scottisb mainland, and these rocks therefore cannot be attached to the local series of the Skye focus.

(b) Augite-andesite dykes, usually with glassy base, and others of acid pitchstone. Dykes and sills of these two rocks are nore numerous in the Isle of Arran, where, as Professor Judd has shown, the two types are closely assuciated, sometimes in composite intrusions. In Skye the known occurrences of acid pitchstone all lie on a narrow belt passing through the granitic tract and having a direction corresponding with that of the dykes themselves. They thus seem to connect themselves with the Local Series as a final and feeble recrudescence of activity about the acid Red Hills centre.

The reversion in the closing stages to intermediate and finally to acid types seems to suggest a new reversal of the order of eruptions, and the composite intrusions (augite-andesite and acid pitchstone) of Arran may perhaps be taken as pointing to a second critical epoch during transitional conditions. These sporadic manifestations of an igneous activity nearing its point of extinction do not, however, afford any very firm ground for such deductions.

VI.-Geological Notes on the Neighbodrhood of Ladismith, Natal. No. 1 : ON some Igneous Rochs.

By Dr. H. Exton, F.G.S.

(Communicated by Professor T. Rupert Jones, F.R.S., F.G.S.)

$\mathrm{W}$

RITING from the Station Hospital at Ladysmith, Dr. Henry Exton, F.G.S., has communicated his observations on the geology of the country near Ladysmith, in the northern part of Natal, in letters to Professor T. Rupert Jones. A very noticeable geological feature is the prevalence of an igneous rock (intrusive andesitic diabase) on all the hills from Umbulwana, four miles east by south from Ladysmith, to the famed Spion Kop, sixteen miles west from here.

This rock covers all the hills, in rounded, smooth, and almost polished boulder-like blocks, of a rusty brown hue on the surface, with a clean blue crystalline fracture, and giving out a ringing sound when struck. It is called by the Dutch yzad-klip (ironstone). The hill-sides around about here can be ascended on foot only where a military road has been cleared to the summit. The slopes of the hills are so profusely strewn with the rounded ironstone blocks that riding along them is impossible, and even walking is a tedious task. The surface of the boulders is generally so rounded and smooth that one has to tread between them, not upon them, as the foot is apt to slide off. Of course, on the summits, where these rocks are in mass, the rounding of the edges is not so apparent, but they are alike weathered to a rich brown colour, very different from the blue crystalline surface of a recent fracture. 